\title{
Plasma acylated and plasma unacylated ghrelin: useful new biomarkers in patients with neuroendocrine tumors?
}

\section{Roxanne C S van Adrichem', Aart Jan van der Lely², Martin Huisman², Piet Kramer2, Richard A Feelders', Patric J D Delhanty ${ }^{2}$ and Wouter W de Herder ${ }^{1}$}

${ }^{1}$ Department of Internal Medicine, Sector of Endocrinology, ENETS Centre of Excellence for Neuroendocrine Tumors, Erasmus MC, Rotterdam, The Netherlands

${ }^{2}$ Department of Internal Medicine, Erasmus MC, Rotterdam, The Netherlands

\begin{abstract}
To date, the value of fasting plasma acylated ghrelin (AG) and unacylated ghrelin (UAG) as potential novel biomarkers in patients with neuroendocrine tumors (NETs) is unknown. The aims of this study are to (i) compare fasting AG and UAG levels between nonobese, nondiabetic NET patients $(N=28)$ and age- $( \pm 3$ years $)$ and sex-matched nonobese, nondiabetic controls $(N=28)$; and (ii) study the relationship between $A G, U A G$, and AG/UAG ratios and biochemical (chromogranin-A (CgA) and neuron-specific enolase (NSE) levels) and clinical parameters (age at diagnosis, sex, primary tumor location, carcinoid syndrome, ENETS TNM classification, Ki-67 proliferation index, grading, prior incomplete surgery) in NET patients. Fasting venous blood samples $(N=56)$ were collected and directly stabilized with 4-(2-aminoethyl) benzenesulfonyl fluoride hydrochloride after withdrawal. Plasma AG and UAG levels were determined by ELISA. Expression of ghrelin was examined in tumor tissue by immunohistochemistry. There were no significant differences between NET patients and controls in AG (median: $62.5 \mathrm{pg} / \mathrm{mL}$, IQR: $33.1-112.8$ vs median: $57.2 \mathrm{pg} / \mathrm{mL}$, IQR: 26.7-128.3, $P=0.66$ ) and UAG in levels (median: 76.6 pg/mL, IQR: 35.23-121.7 vs median: 64.9, IQR: 27.5-93.1, $P=0.44$ ). No significant correlations were found between AG, UAG, and AG/UAG ratios versus biochemical and clinical parameters in NET patients with the exception of age at diagnosis (AG: $\rho=-0.47, P=0.012$; AG/UAG ratio: $\rho=-0.50, P=0.007$ ) and baseline chromogranin-A levels (AG/UAG ratio: $\rho=-0.44, P=0.019$ ). In our view, fasting plasma acylated and unacylated ghrelin appear to have no value as diagnostic biomarkers in the clinical follow-up of patients with NETs.
\end{abstract}

Correspondence should be addressed to W W de Herder

Email

w.w.deherder@erasmusmc.nl

\footnotetext{
Key Words

- neuroendocrine tumors (NETs)

- human unacylated ghrelin (UAG)

- human acylated ghrelin (AG)

- biomarker
}

\section{Introduction}

Ghrelin is a gut-brain hormone that is produced predominantly by gastric X/A-like neuroendocrine cells $(1,2)$. Ghrelin exists in two forms: acylated ghrelin (AG) and unacylated ghrelin (UAG). About 50\% of circulating ghrelin is in the acylated form $(3,4)$ and exerts its functions through the growth hormone secretagogue receptor type 1a (GHSR1a) $(5,6)$. Acylation of ghrelin, which is required for its ability to activate the GHSR1a in vivo, is performed by the enzyme ghrelin O-acyltransferase (GOAT) $(5,7,8)$. UAG does http://www.endocrineconnections.org DOI: 10.1530/EC-16-0021 (c) 2016 The authors Published by Bioscientifica Ltd
This work is licensed under a Creative Commons Attribution-NonCommercial 4.0 International License. 
not activate the GHSR1a at physiological concentrations $(5,9)$. Therefore, UAG has been considered as an inactive degradation product of ghrelin $(2,10)$. However, as recently reported, UAG could also act as a separate hormone in several physiological and pathophysiological conditions, independent from AG (9).

AG seems to be involved in different endocrine and nonendocrine processes $(2,11,12,13,14,15,16)$. Neoplastic effects of ghrelin have been reported as well including: cell proliferation, cell migration, cell invasion, inflammation, apoptosis, and angiogenesis $(17,18,19)$.

Neuroendocrine tumors (NETs) are rare tumors characterized by the hypersecretion of several bioamines and peptides $(20,21)$. NETs can also express ghrelin and its receptors $(14,22)$. Although most NETs release ghrelin, hyperghrelinemia has been reported in only 11 patients with NETs $(23,24,25,26,27)$.

The function of ghrelin in NETs is not well understood. It has been suggested that ghrelin could be responsible for the striking maintenance of body mass index (BMI) that can be observed in NET patients $(15,28)$. Although total serum ghrelin levels in NET patients were reported to be positively correlated with tumor burden (29), total plasma ghrelin seems not to be a useful biomarker since total plasma ghrelin levels did not discriminate between patients with NETs and healthy controls (23). Currently, there are no data on the clinical usefulness of the two isoforms of ghrelin, AG and UAG, as potential biomarkers in patients with NETs. Examining the relationship between these two isoforms has relevance, since it is becoming clearer that levels of ghrelin acylation are regulated and not constant (4). For example, the ratio of AG/UAG has been found to be linked with metabolic status $(30,31)$.

Therefore, the aims of this study are to (i) compare fasting AG and UAG levels between nonobese, nondiabetic NET patients $(N=28)$ and age- ( \pm 3 years $)$ and sex-matched nonobese, nondiabetic controls $(N=28)$; and (ii) study the relationship between $A G, U A G$, and $A G / U A G$ ratios and biochemical (chromogranin-A (CgA) and neuronspecific enolase (NSE) levels) and clinical parameters (age at diagnosis, sex, primary tumor location, carcinoid syndrome, ENETS TNM classification (32, 33), Ki-67 proliferation index, grading, prior incomplete surgery) in NET patients.

\section{Subjects and methods}

\section{NET patients}

Between March 2014 and March 2015, 28 Caucasian, nonobese, nondiabetic patients who were referred with a newly diagnosed neuroendocrine tumor were recruited. The diagnosis of an NET was based on biochemical, histological, and clinical parameters. The primary NETs were originating from the small intestine, pancreas, stomach, lung, or had an unknown origin.

Patients were eligible for the study if they were medical treatment naive, were not obese, and had neither metabolic syndrome nor diabetes mellitus. Prior surgery with incomplete removal of the NET was permitted for inclusion into the study.

All NET patients gave written informed consent before inclusion in this study, which was approved by the Medical Ethics Committee of the Erasmus University MC in Rotterdam.

\section{Controls}

All patients with NETs were sex- and age-matched to 28 healthy Caucasian, nonobese, nondiabetic controls (within a range of \pm 3 years of age). Patients were paired with age-matched controls since a study in men found an age-dependent decline in AG concentrations (34). Controls were healthy volunteers from Erasmus MC, Rotterdam. All controls were recruited prospectively between January 2015 and March 2015.

Exclusion criteria for the controls were the following: past or existent malignancies; endocrine disorders including diabetes mellitus, acromegaly, Cushing syndrome; metabolic syndrome; any active use of glucocorticoids; active inflammatory or infectious disease; past gastric surgery, kidney, or liver function abnormalities; epilepsy; and psychiatric and eating disorders.

Controls gave their written informed consent before inclusion into the study.

\section{Materials}

Vacutainers were obtained from Becton Dickinson (Breda, Netherlands; cat\# 367899; $6 \mathrm{~mL}$ K2 EDTA). 4-(2-aminoethyl) benzenesulfonyl fluoride hydrochloride (Pefabloc, SC AEBSF) was purchased from Roche Applied Science (cat\# 11429876001; Almere, Netherlands). Stock solutions of AEBSF were prepared in distilled water to give a final concentration of $200 \mathrm{mg} / \mathrm{mL}$ AEBSF.

Human AG and UAG are determined by a double-antibody sandwich technique. The enzyme immunoassay (EIA) kits were obtained from Bertin Pharma (Montigny-le-Bretonneux, France; A05106 and A05119, respectively). 


\section{Blood collection, AEBSF treatment, and storage}

Overnight fasting venous blood samples for the measurement of plasma AG and plasma UAG were withdrawn and collected in EDTA tubes. One $6 \mathrm{~mL}$ EDTA tube per patient or control was collected.

Immediately after withdrawal, AEBSF (dilution 1:100) was directly added to all blood samples to prevent des-acylation of AG $(3,35)$. Whole blood was carefully mixed by inversion and stored on water ice $\left(4^{\circ} \mathrm{C}\right)$ until centrifugation at $2500 \mathrm{~g}$ at $4^{\circ} \mathrm{C}$ for $5 \mathrm{~min}$. Plasma of these venous blood samples was then rapidly aliquoted, four $1.5 \mathrm{~mL}$ Eppendorf tubes with $300 \mathrm{~mL}$ each. All plasma samples were stored at $-80^{\circ} \mathrm{C}$ until the assay was performed. AEBSF was stored for a maximum of 1 month after dilution.

\section{Acylated and unacylated ghrelin EIAs}

After thawning on ice, plasma samples of all NET patients $(N=28)$ and sex- and age-matched controls $(N=28)$ were centrifuged for $1 \mathrm{~min}$ at $1500 \mathrm{~g}, 4^{\circ} \mathrm{C}$ and kept on ice before

Table 1 Patient and tumor characteristics $(N=28)$. Data are expressed as median \pm interquartile range (IQR).

\begin{tabular}{l} 
Parameters \\
\hline Age at diagnosis (range) \\
Sex - male (\%) \\
Primary tumor location \\
Small intestine \\
Pancreas \\
Stomach \\
Lung \\
Unknown \\
Carcinoid syndrome - yes (\%) \\
Baseline serum CgA ( $\mu$ g/L) (IQR) \\
Baseline serum NSE ( $\mu$ g/L) (IQR) \\
Mean 24h urinary 5-HIAA excretion/ \\
creatinine ratio (mmol/mol) \\
Disease stage (\%) \\
Stage I \\
Stage IIA \\
Stage IIIB \\
Stage IV \\
ENETS TNM classification (\%) \\
M0 \\
M1 \\
Ki-67 proliferation index (IQR) \\
Grading (\%) \\
G1 \\
G2 \\
G3 \\
Unknown \\
Prior incomplete surgical \\
resection - yes (\%) \\
\hline
\end{tabular}

\begin{tabular}{c}
\hline Total \\
\hline $56(35-81)$ \\
$15(53.6)$ \\
$19(67.8)$ \\
$3(10.7)$ \\
$1(3.6)$ \\
$4(14.3)$ \\
$1(3.6)$ \\
$15(53.6)$ \\
$155.5(56.0-493.8)$ \\
$83.0(24.0-398.3)$ \\
$14.9(12.4-22.8)$ \\
\\
$1(3.6)$ \\
$2(7.1)$ \\
$6(21.4)$ \\
$19(67.9)$ \\
$11(39.3)$ \\
$17(60.7)$ \\
$3(2.0-10.0)$ \\
$9(32.1)$ \\
$17(60.7)$ \\
$1(3.6)$ \\
$1(3.6)$ \\
$18(64.3)$ \\
\end{tabular}

http://www.endocrineconnections.org DOI: 10.1530/EC-16-0021 Published by Bioscientifica Ltd

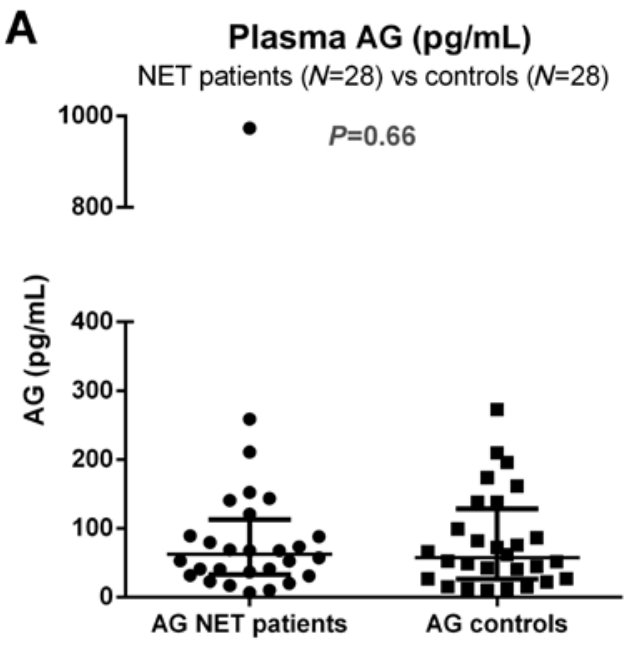

B Plasma UAG $(\mathrm{pg} / \mathrm{mL})$

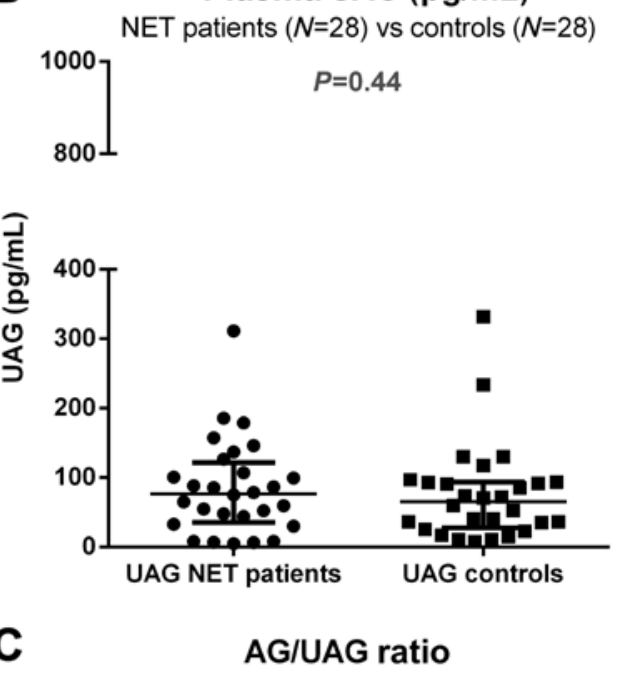
NET patients $(N=28)$ vs controls $(N=28)$

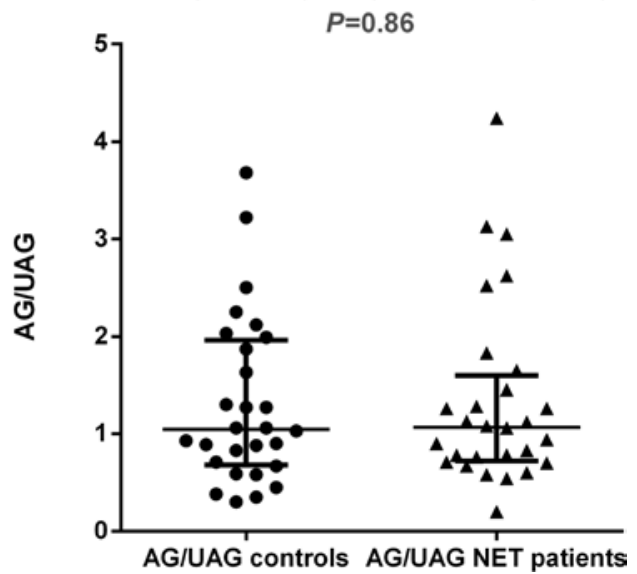

Figure 1

Plasma acylated ghrelin (AG), plasma unacylated ghrelin (UAG), and acylated ghrelin/unacylated ghrelin (AG/UAG) ratio in Caucasian, nonobese, nondiabetic NET patients $(N=28)$ versus sex- and age-matched healthy Caucasian, nonobese, nondiabetic controls $(N=28)$. Data are expressed as median \pm interquartile range (IQR).

This work is licensed under a Creative Commons Attribution-NonCommercial 4.0 International License. 
A Primary NET localization
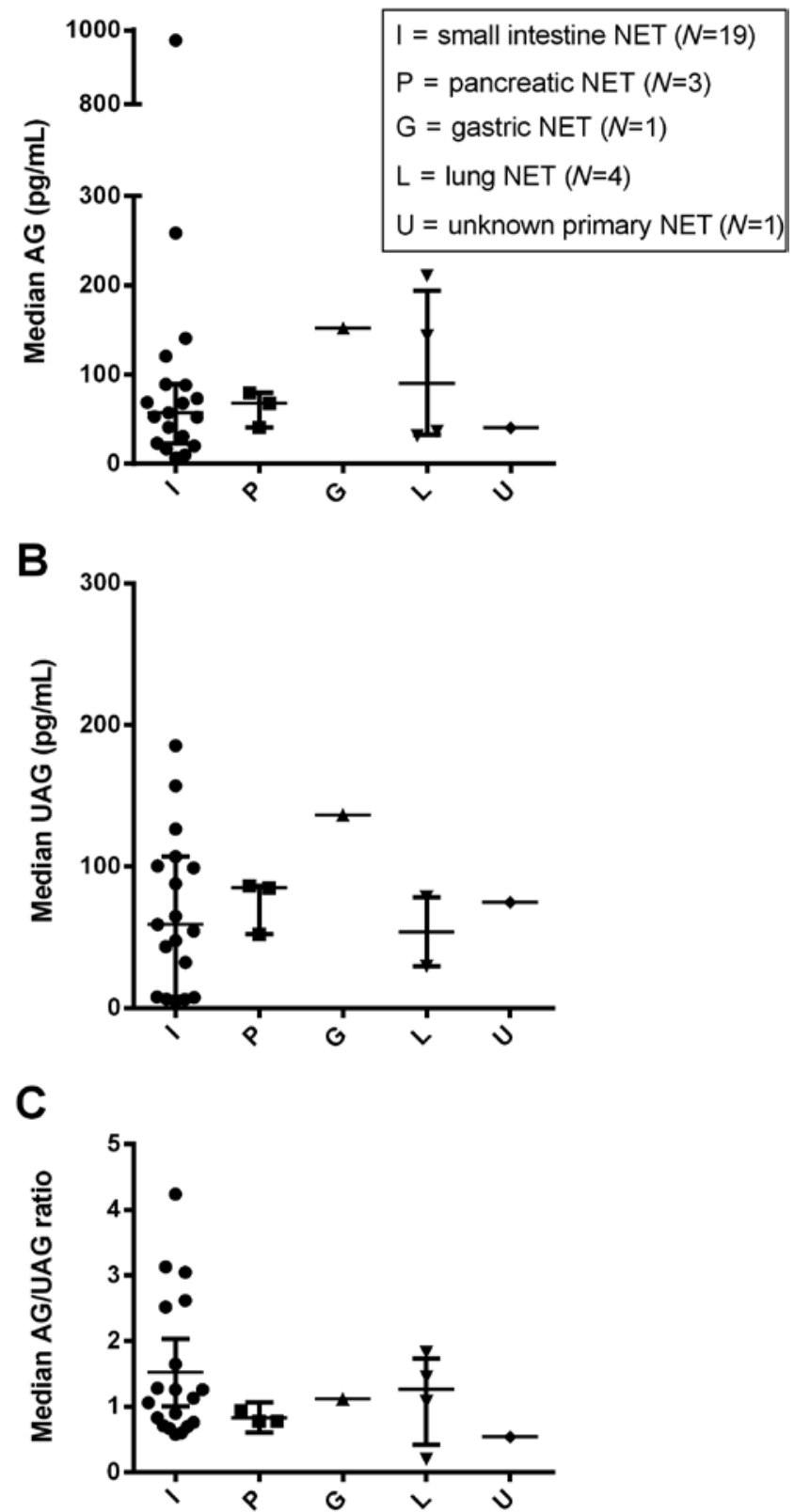

Figure 2

Primary tumor localization in patients with neuroendocrine tumors (NETs), and the distribution of plasma acylated ghrelin (AG), plasma unacylated ghrelin (UAG), and acylated ghrelin/unacylated ghrelin (AG/UAG) ratio. Data are expressed as median \pm interquartile range (IQR).

transferring to the assay plates. All samples were measured in duplicate $(50 \mu \mathrm{L} /$ well) according to the manufacturer's protocol (3).

A cubic polynomial fitting was used to determine concentrations from the calibration curves. This resulted in $r^{2}$ values $>0.99$ in the majority of the assays. The intraassay percent coefficient of variation (\%CVs) for AG was

\begin{tabular}{|lr}
\hline http://www.endocrineconnections.org & ○ 2016 The authors \\
DOI: 10.1530/EC-16-0021 & Published by Bioscientifica Ltd
\end{tabular}
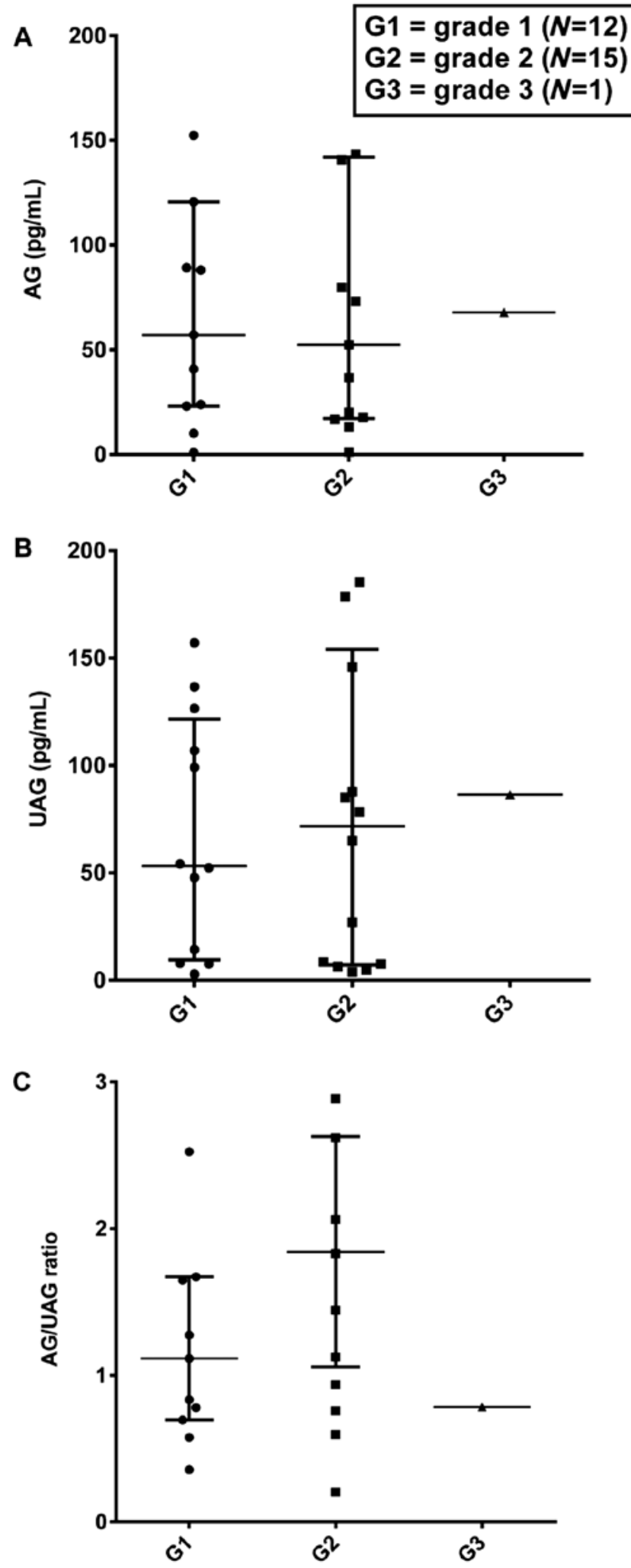

Figure 3

Plasma acylated ghrelin (AG) and plasma unacylated ghrelin (UAG) in Caucasian, nonobese, nondiabetic NET patients $(N=28)$ distributed according to tumor grading. Data are expressed as median \pm interquartile range (IQR). 
5.8 and for $\mathrm{UAG}$ 1.8. Interassay $\% \mathrm{CVs}$ for $\mathrm{AG}$ was 14.7 and for UAG 17.3.

\section{Immunohistochemistry}

Protein expression of total ghrelin was investigated in a small intestine NET tissue sample of one patient. Normal stomach tissue was used as a positive control. Mounted sections were deparaffinized, blocked for endogenous peroxidase activity, and rinsed with water. Following antigen retrieval, sections were incubated overnight at $4^{\circ} \mathrm{C}$ with the antiacylated ghrelin antiserum (N-terminal antibody (\#404,4-4); dilution 1:2000), which was kindly provided by Professor Hiroshi Hosoda. Next, sections were incubated with Brightvision poly-HRP-Anti Ms/Rb/Rt IgG kit (Immunologic, Duiven, The Netherlands), and the peroxidase activity was developed with $0.07 \%$ 3,3-diaminobenzidine tetrahydrochloride (Sigma-Aldrich Chemie BV, Zwijndrecht, The Netherlands). Finally, sections were counterstained with hematoxylin.

\section{Clinical and tumor characteristics}

Clinical data of NET patients, including age at diagnosis, sex, primary tumor location, carcinoid syndrome, baseline serum CgA levels, baseline serum NSE levels, ENETS TNM classification, Ki-67 proliferation index, grading, and prior incomplete surgery, were collected from patient's medical records.

\section{Statistical analysis}

Analyses were performed using SPSS software (version 21 for Windows; SPSS) and GraphPad Prism Version 6.04 (GraphPad Software). Comparisons between NET patients and controls were analyzed by Wilcoxon signedranks tests, Mann-Whitney tests, and Fisher's exact tests. Correlation analyses were done using Spearman's rank correlation test. The results are expressed as median \pm interquartile range (IQR). $P$-values of $<0.05$ were considered to be statistically significant.

\section{Results}

Characteristics of the NET patients and their tumors are summarized in Table 1. Patients with NETs were matched with their controls by age and sex. Patients had a median age of 57.5 years (IQR: 50.3-66.5) and controls had 58.0 years (IQR: 50.0-64.0).

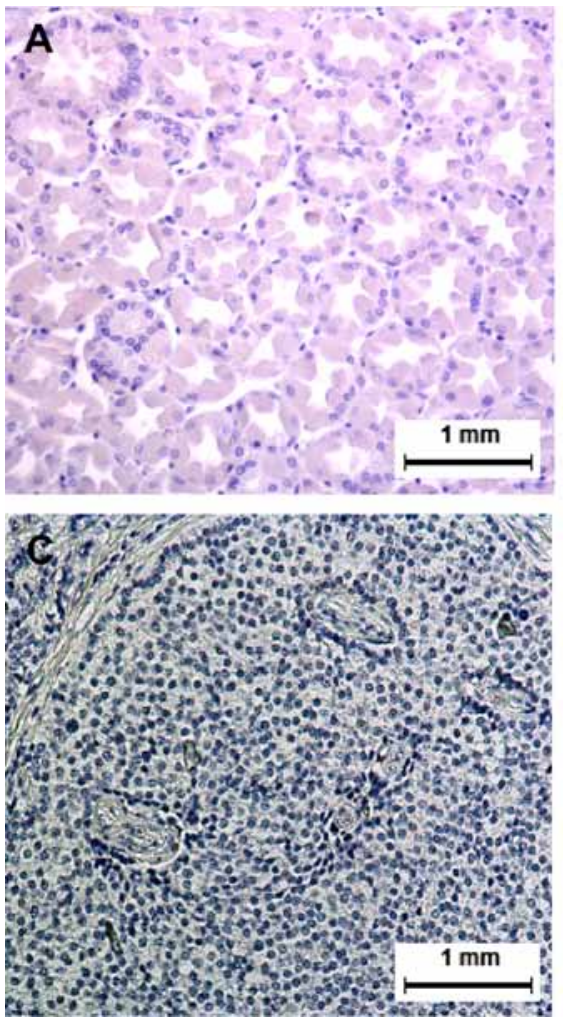
DOI: 10.1530/EC-16-0021
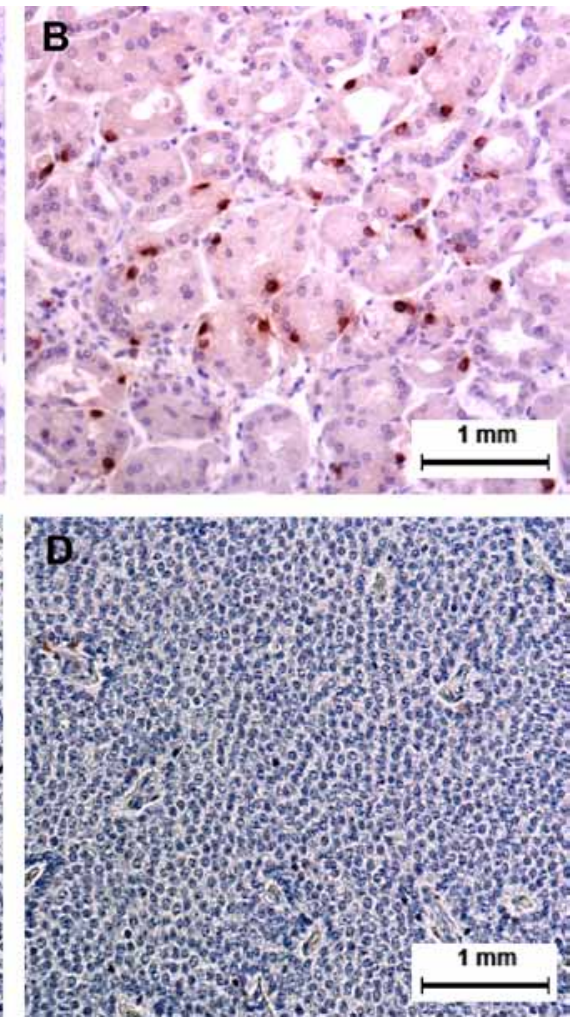

\section{Figure 4}

Immunohistochemistry: section of normal stomach tissue (panel A, magnification 10x). immunohistochemical staining of ghrelin on normal stomach tissue (panel B, magnification $10 \times$ ), section of small intestine NET tissue (panel $C$ magnification $20 \times$ ), and immunohistochemical staining of ghrelin small intestine NET tissue (panel D, magnification 20x). The scale bar is set on $1 \mathrm{~mm}$. 
Plasma AG and UAG levels in NET patients $(N=28)$ and their sex- and age-matched controls $(N=28)$ are shown (Fig. 1). Levels of plasma AG (Fig. 1A) and plasma UAG (Fig. 1B) showed a wide range in both patients and controls. Healthy controls had 'reference levels' of AG that ranged from 10 to $273 \mathrm{pg} / \mathrm{mL}$ and plasma UAG levels of $8-331 \mathrm{pg} / \mathrm{mL}$. Median plasma AG levels in NET patients and controls were 62.5 (IQR: 33.1-112.8) and 57.2 (IQR: 26.7-128.3, P=0.66), respectively (Fig. 1A). Median plasma UAG levels in NET patients and controls were 76.6 (IQR: 35.2-121.7) and 64.9 (IQR: 27.5-93.1, $P=0.44$ ), respectively (Fig. 1B). The highest observed AG level of $973.2 \mathrm{pg} / \mathrm{mL}$ and highest UAG level of $311.2 \mathrm{pg} / \mathrm{mL}$ were observed in the same patient with a small intestine NET.

The AG/UAG ratios in NET patients and the control population are provided (Fig. 1C). The median AG/UAG ratios in NET patients were 1.1 (IQR: 0.7-1.6), which were not significantly different from the median AG/UAG ratios in controls (1.0, IQR: $0.7-2.0, P=0.86)$.

Figure $2 \mathrm{~A}$ shows the primary tumor localization in NET patients and the distribution of plasma AG. Plasma UAG levels are shown in Fig. 2B, and AG/UAG ratio in Fig. 2C. All data are expressed as median \pm interquartile range (IQR).

In Fig. 3A, tumor grading in NET patients and the distribution of plasma AG is shown. Plasma UAG levels and tumor grading are shown in Fig. 3B, and the AG/UAG ratio in Fig. 3C. All data are expressed as median \pm interquartile range (IQR).

There were no significant differences in plasma AG levels $(P=0.60)$, plasma UAG levels $(P=0.55)$, and AG/UAG ratio $(P=0.53)$ between NET patients who did not undergo surgery and those who did undergo surgery with incomplete tumor removal.

We found no statistically significant correlations in NET patients between plasma AG, UAG, and AG/UAG ratios versus biochemical and clinical parameters with the exception of $A G$ and $A G / U A G$ ratio versus age at diagnosis $(\rho=-0.47, P=0.012 ; P=0.46 ; \quad \rho=-0.50$, $P=0.007)$ and AG/AUG/ratio versus baseline CgA levels $(P=0.88, \quad P=0.15 ; \quad \rho=-0.44, \quad P=0.019): \operatorname{sex} \quad(P=0.46$, $0.41, P=0.41)$, primary tumor location $(P=0.41, P=0.38$, $P=0.19)$, carcinoid syndrome $(P=0.46, P=0.41, P=0.41)$, baseline serum NSE levels $(P=0.47, P=0.36, P=0.10)$, ENETS TNM classification $(P=0.39, P=0.39, P=0.39)$, Ki-67 proliferation index $(P=0.92, P=0.99, P=0.65)$, grading $(P=0.40, P=0.40, P=0.86)$, and prior incomplete surgery $(P=0.47, P=0.41, P=0.42)$.
Immunohistochemistry was performed on a small intestine NET tissue sample of the patient with the highest plasma AG and UAG levels. Staining showed no immunoreactive NET cells for ghrelin (Fig. 4).

\section{Discussion}

This is the first study in which we measured fasting plasma acylated and unacylated ghrelin levels in a series of Caucasian, nonobese, nondiabetic NET patients and healthy sex- and age-matched Caucasian, nonobese, nondiabetic controls, using a sensitive assay.

Recently, we published the results of a noninterventional study in which we compared two different, commercially available, ELISA formats of AG and UAG in venous plasma stabilized or not with 4-(2-aminoethyl) benzenesulfonyl fluoride (AEBSF) and stored for $0-6$ months at $-20^{\circ} \mathrm{C}$ or $-80^{\circ} \mathrm{C}$ (3). We observed that when measured in AEBSF-stabilized plasma, the AG/UAG ratio is markedly higher than previously described and that UAG is a physiological component of the circulation. This highlights the importance of immediately stabilizing blood samples on collection for determination of both AG and UAG concentrations and provides a valuable tool for their measurement in physiological and interventional studies (3).

Trivedi and coworkers (36) showed that AEBSF may inhibit acetylcholinesterase (AChE) activity from the kits and thus may change AG levels. However, this problem of AEBSF suppressing AChE activity is circumvented using the applied processing method and Bertin Pharma EIA kits described by Delhanty and coworkers (3). Therefore, it is unlikely that because of technical issues, AG and UAG overlap and have almost the same reference range in both controls and NET groups.

Using an AEBSF-stabilized assay, our results are of interest as we found no significant differences in plasma AG levels and plasma UAG levels between NET patients and their matched controls. Therefore, we are quite certain that fasting plasma AG and UAG levels are no suitable diagnostic biomarkers in patients with NETs. Although the study was performed with a relatively small group of NET patients, we suspect that lack of power does not play a major role in our study.

We have also shown in this paper that incorrect processing of blood samples leads to raised UAG levels likely through conversion of AG to UAG. Also, we get roughly similar low levels of AG and UAG, and AG/UAG http://www.endocrineconnections.org DOI: 10.1530/EC-16-0021
(๔) 2016 The authors Published by Bioscientifica Ltd

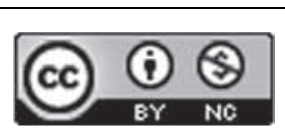

This work is licensed under a Creative Commons Attribution-NonCommercial 4.0 International License. 
ratios to that described by Tong and coworkers (37) using a different two-site sandwich ELISA that does not use AChE as an indicator.

We observed in our series of NET patients significant negative correlations of $A G$ and the $A G / U A G$ ratio versus age at diagnosis. These data are in accordance with the observation of an age-dependent decline of AG concentrations found in men by Nass and coworkers. Additionally, we detected in NET patients a significant negative correlation of the AG/AUG ratio versus baseline CgA levels. However, these AG/UAG ratios were not significantly different between patients and controls. Our hypothesis is that AG/UAG ratios reflect a favorable metabolic status for NETs. AG/UAG ratio were not significantly different between users of proton pump inhibitors (PPIs) and patients not taking PPIs $(P=0.42)$.

Healthy controls had 'reference levels' of AG that ranged from 10 to $273 \mathrm{pg} / \mathrm{mL}$ and plasma UAG levels of $8-331 \mathrm{pg} / \mathrm{mL}$. This is not an unusual finding in fasted subjects. For example, Liu and coworkers (4) find a range of $43-366 \mathrm{pg} / \mathrm{mL}$ for AG in four volunteers using a similar method of blood sample stabilization.

In one NET patient, the fasting plasma AG and UAG levels of 973.2 and $311.2 \mathrm{pg} / \mathrm{mL}$, respectively, exceeded the control 'reference values' of plasma AG and plasma UAG.

This particular 37-year-old male patient is the first case report of hyperghrelinemia associated by a small intestinal NET. He has a stage IIA, grade 2 NET that was found accidently after a short period of abdominal pain and fever. At the time of referral, he had no other clinical symptoms. Laboratory examination showed a normal baseline CgA level and normal $24 \mathrm{~h}$ urinary 5-hydroxyindoleacetic acid (5-HIAA) excretion, but an elevated baseline NSE level $(21.1 \mu \mathrm{g} / \mathrm{L}$, maximum reference value: $16.2 \mu \mathrm{g} / \mathrm{L}$ ). IHC on his small intestinal NET biopsy showed no immunoreactivity for ghrelin, however. This finding suggests that the NET does not seem to be directly responsible for the hyperghrelinemia. Although immunohistochemical staining on a nonrepresentative incidentally ghrelin-negative tumor area from a tumor with ghrelin in other areas could not be excluded.

In the literature, only 11 NET patients with elevated total and/or acylated ghrelin levels have been described $(23,24,25,26,27)$. Of these patients, only one patient had clinical symptoms of hypersecretion of vasoactive products by the NET. This particular patient was especially suffering from diarrhea, tiredness, and anemia, and he developed diabetes mellitus as well.
According to the authors, these symptoms were caused by the patient's ghrelinoma. However, overproduction of other more common hormones including gastrin, glucagon, vasoactive intestinal peptide, and 5-hydroxyindoleacetic acid which could explain the signs and symptoms was not excluded. Therefore, we could not confirm that ghrelin overproduction is of clinical importance and a 'ghrelinoma syndrome' probably does not exist. This is based on our finding that plasma AG and UAG levels are not significantly different between sex- and age-matched healthy individuals and NET patients. In addition, we found no significant correlations between plasma AG and UAG levels versus biochemical and clinical parameters. We suggest that the elevated AG and UAG levels in the particular NET patient were caused by nontumoral-related processes in which ghrelin plays a role.

In conclusion, we observed that, using a sensitive AEBSF-stabilized ghrelin assay, fasting plasma AG and UAG are useless as clinical diagnostic biomarkers in patients with an NET.

\section{Declaration of interest}

Wouter de Herder and Richard Feelders attend advisory boards and have received speakers fees from Ipsen and Novartis. Aart Jan van der Lely is a shareholder and co-founder of Alizé Pharma SA.

\section{Funding}

This research did not receive any specific grant from any funding agency in the public, commercial, or not-for-profit sector

\section{Acknowledgments}

The authors thank Ms Sjaan Poldermans and Ms Sanne Franck for their excellent assistance with the collection of blood samples.

\section{References}

1 Date Y, Kojima M, Hosoda H, Sawaguchi A, Mondal MS, Suganuma T, Matsukura S, Kangawa K \& Nakazato M. Ghrelin, a novel growth hormone-releasing acylated peptide, is synthesized in a distinct endocrine cell type in the gastrointestinal tracts of rats and humans. Endocrinology 2000141 4255-4261. (doi:10.1210/en.141.11.4255)

2 Kojima M, Hosoda H, Date Y, Nakazato M, Matsuo H \& Kangawa K. Ghrelin is a growth-hormone-releasing acylated peptide from stomach. Nature 1999402 656-660. (doi:10.1038/45230)

3 Delhanty PJ, Huisman M, Julien M, Mouchain K, Brune P, Themmen AP, Abribat T \& van der Lely AJ. The acylated (AG) to unacylated (UAG) ghrelin ratio in esterase inhibitor-treated blood is higher than previously described. Clinical Endocrinology 201582 142-146. (doi:10.1111/cen.12489)

4 Liu J, Prudom CE, Nass R, Pezzoli SS, Oliveri MC, Johnson ML, Veldhuis P, Gordon DA, Howard AD, Witcher DR, et al. Novel ghrelin assays provide evidence for independent regulation of ghrelin http://www.endocrineconnections.org DOI: 10.1530/EC-16-0021 (c) 2016 The authors Published by Bioscientifica Ltd
This work is licensed under a Creative Commons Attribution-NonCommercial 4.0 International License. 
acylation and secretion in healthy young men. Journal of Clinical Endocrinology \& Metabolism 200893 1980-1987. (doi:10.1210/jc.20072235)

5 Delhanty PJ, Sun Y, Visser JA, van Kerkwijk A, Huisman M, van Ijcken WF, Swagemakers S, Smith RG, Themmen AP, van der Lely AJ, et al. Unacylated ghrelin rapidly modulates lipogenic and insulin signaling pathway gene expression in metabolically active tissues of GHSR deleted mice. PLOS ONE 20105 e11749. (doi:10.1371/journal. pone.0011749)

6 Gronberg M, Tsolakis AV, Holmback U, Stridsberg M, Grimelius L \& Janson ET. Ghrelin and obestatin in human neuroendocrine tumors: expression and effect on obestatin levels after food intake. Neuroendocrinology 201397 291-299. (doi:10.1159/000345366)

7 Gutierrez JA, Solenberg PJ, Perkins DR, Willency JA, Knierman MD, Jin Z, Witcher DR, Luo S, Onyia JE, Hale JE, et al. Ghrelin octanoylation mediated by an orphan lipid transferase. PNAS 2008 105 6320-6325. (doi:10.1073/pnas.0800708105)

8 Yang J, Brown MS, Liang G, Grishin NV \& Goldstein JL. Identification of the acyltransferase that octanoylates ghrelin, an appetitestimulating peptide hormone. Cell 2008132 387-396. (doi:10.1016/j. cell.2008.01.017)

9 Delhanty PJ, Neggers SJ \& van der Lely AJ. Mechanisms in endocrinology: Ghrelin: the differences between acyl- and des-acyl ghrelin. European Journal of Endocrinology 2012167 601-608. (doi:10.1530/EJE-12-0456)

10 Gauna C, van de Zande B, van Kerkwijk A, Themmen AP, van der Lely AJ \& Delhanty PJ. Unacylated ghrelin is not a functional antagonist but a full agonist of the type 1a growth hormone secretagogue receptor (GHS-R). Molecular and Cellular Endocrinology 2007274 30-34. (doi:10.1016/j.mce.2007.05.010)

11 Cummings DE \& Overduin J. Gastrointestinal regulation of food intake. Journal of Clinical Investigation 2007 117 13-23. (doi:10.1172/ JCI30227)

12 Delhanty PJ \& van der Lely AJ. Ghrelin and glucose homeostasis. Peptides 201132 2309-2318. (doi:10.1016/j.peptides.2011.03.001)

13 Nakazato M, Murakami N, Date Y, Kojima M, Matsuo H, Kangawa K $\&$ Matsukura S. A role for ghrelin in the central regulation of feeding. Nature 2001409 194-198. (doi:10.1038/35051587)

14 Papotti M, Cassoni P, Volante M, Deghenghi R, Muccioli G \& Ghigo E. Ghrelin-producing endocrine tumors of the stomach and intestine. Journal of Clinical Endocrinology \& Metabolism 200186 5052-5059.

$15 \mathrm{Vu}$ JP, Wang HS, Germano PM \& Pisegna JR. Ghrelin in neuroendocrine tumors. Peptides 201132 2340-2347. (doi:10.1016/j. peptides.2011.10.006)

16 Wren AM, Small CJ, Ward HL, Murphy KG, Dakin CL, Taheri S, Kennedy AR, Roberts GH, Morgan DG, Ghatei MA, et al. The novel hypothalamic peptide ghrelin stimulates food intake and growth hormone secretion. Endocrinology $20001414325-4328$.

17 Cassoni P, Papotti M, Ghe C, Catapano F, Sapino A, Graziani A, Deghenghi R, Reissmann T, Ghigo E \& Muccioli G. Identification characterization, and biological activity of specific receptors for natural (ghrelin) and synthetic growth hormone secretagogues and analogs in human breast carcinomas and cell lines. Journal of Clinical Endocrinology \& Metabolism 200186 1738-1745. (doi:10.1210/ jcem.86.4.7402)

18 Chopin LK, Seim I, Walpole CM \& Herington AC. The ghrelin axis does it have an appetite for cancer progression? Endocrine Reviews 201233 849-891. (doi:10.1210/er.2011-1007)

19 Nanzer AM, Khalaf S, Mozid AM, Fowkes RC, Patel MV, Burrin JM, Grossman AB \& Korbonits M. Ghrelin exerts a proliferative effect on a rat pituitary somatotroph cell line via the mitogen-activated protein kinase pathway. European Journal of Endocrinology $2004151233-240$. (doi:10.1530/eje.0.1510233)
20 de Herder WW. Biochemistry of neuroendocrine tumours. Best Practice \& Research Clinical Endocrinology \& Metabolism 200721 33-41.

21 Modlin IM, Oberg K, Chung DC, Jensen RT, de Herder WW, Thakker RV, Caplin M, Delle Fave G, Kaltsas GA, Krenning EP, et al. Gastroenteropancreatic neuroendocrine tumours. Lancet Oncology 20089 61-72. (doi:10.1016/S1470-2045(07)70410-2)

22 Volante M, Allia E, Gugliotta P, Funaro A, Broglio F, Deghenghi R, Muccioli G, Ghigo E \& Papotti M. Expression of ghrelin and of the GH secretagogue receptor by pancreatic islet cells and related endocrine tumors. Journal of Clinical Endocrinology \& Metabolism 2002 87 1300-1308.

23 Corbetta S, Peracchi M, Cappiello V, Lania A, Lauri E, Vago L, Beck-Peccoz P \& Spada A. Circulating ghrelin levels in patients with pancreatic and gastrointestinal neuroendocrine tumors: identification of one pancreatic ghrelinoma. Journal of Clinical Endocrinology \& Metabolism 200388 3117-3120. (doi:10.1210/jc.2002-021842)

24 Ekeblad S, Lejonklou MH, Grimfjard P, Johansson T, Eriksson B, Grimelius L, Stridsberg M, Stålberg P \& Skogseid B. Co-expression of ghrelin and its receptor in pancreatic endocrine tumours. Clinical Endocrinology 200766 115-22. (doi:10.1111/j.1365-2265.2006.02695.x)

25 Falkmer UG, Gustafsson T, Wenzel R, Wierup N, Sundler F, Kulkarni H, Baum RP \& Falkmer SE. Malignant presacral ghrelinoma with long-standing hyperghrelinaemia. Upsala Journal of Medical Sciences 201520 1-6. (doi:10.3109/03009734.2015.1054453)

26 Tsolakis AV, Portela-Gomes GM, Stridsberg M, Grimelius L, Sundin A, Eriksson BK, Oberg KE \& Janson ET. Malignant gastric ghrelinoma with hyperghrelinemia. Journal of Clinical Endocrinology \& Metabolism 200489 3739-3744. (doi:10.1210/ jc.2003-032118)

27 Walter T, Chardon L, Hervieu V, Cohen R, Chayvialle JA, Scoazec JY \& Lombard-Bohas C. Major hyperghrelinemia in advanced welldifferentiated neuroendocrine carcinomas: report of three cases. European Journal of Endocrinology 2009161 639-645. (doi:10.1530/EJE09-0073)

28 Korbonits M, Jacobs RA, Aylwin SJ, Burrin JM, Dahia PL, Monson JP, Honegger J, Fahlbush R, Trainer PJ, Chew SL, et al. Expression of the growth hormone secretagogue receptor in pituitary adenomas and other neuroendocrine tumors. Journal of Clinical Endocrinology \& Metabolism 199883 3624-3630. (doi:10.1210/jcem.83.10.5210)

29 Wang HS, Oh DS, Ohning GV \& Pisegna JR. Elevated serum ghrelin exerts an orexigenic effect that may maintain body mass index in patients with metastatic neuroendocrine tumors. Journal of Molecular Neuroscience 200733 225-231. (doi:10.1007/s12031-007-0004-9)

30 Barazzoni R, Zanetti M, Ferreira C, Vinci P, Pirulli A, Mucci M, Dore F, Fonda M, Ciocchi B, Cattin L, et al. Relationships between desacylated and acylated ghrelin and insulin sensitivity in the metabolic syndrome. Journal of Clinical Endocrinology \& Metabolism 200792 3935-3940. (doi:10.1210/jc.2006-2527)

31 Kuppens RJ, Diene G, Bakker NE, Molinas C, Faye S, Nicolino M, Bernoux D, Delhanty PJ, van der Lely AJ, Allas S, et al. Elevated ratio of acylated to unacylated ghrelin in children and young adults with Prader-Willi syndrome. Endocrine 201550 633-642. (doi:10.1007/ s12020-015-0614-x)

32 Rindi G, Kloppel G, Alhman H, Caplin M, Couvelard A, de Herder WW, Erikssson B, Falchetti A, Falconi M, Komminoth P, et al. TNM staging of foregut (neuro)endocrine tumors: a consensus proposal including a grading system. Virchows Archiv 2006449 395-401. (doi:10.1007/s00428-006-0250-1)

33 Rindi G, Kloppel G, Couvelard A, Komminoth P, Korner M, Lopes JM, McNicol A-M, Nilsson O, Perren A, Scarpa A, et al. TNM staging of midgut and hindgut (neuro) endocrine tumors: a consensus proposal including a grading system. Virchows Archiv 2007451 757-762. (doi:10.1007/s00428-007-0452-1)

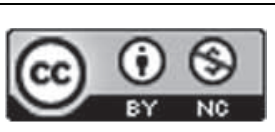

This work is licensed under a Creative Commons Attribution-NonCommercial 4.0 International License. 
34 Nass R, Farhy LS, Liu J, Pezzoli SS, Johnson ML, Gaylinn BD \& Thorner MO. Age-dependent decline in acyl-ghrelin concentrations and reduced association of acyl-ghrelin and growth hormone in healthy older adults. Journal of Clinical Endocrinology \& Metabolism 201499 602-608.

(doi:10.1210/jc.2013-3158)

35 Blatnik M \& Soderstrom CI. A practical guide for the stabilization of acylghrelin in human blood collections. Clinical Endocrinology 2011 74 325-331. (doi:10.1111/j.1365-2265.2010.03916.x)
36 Trivedi A, Babic S \& Chanoine JP. Pitfalls in the determination of human acylated ghrelin plasma concentrations using a double antibody enzyme immunometric assay. Clinical Biochemistry 201245 178-180. (doi:10.1016/j.clinbiochem.2011.10.023)

37 Tong J, Prigeon RL, Davis HW, Bidlingmaier M, Tschop MH \& D'Alessio D. Physiologic concentrations of exogenously infused ghrelin reduces insulin secretion without affecting insulin sensitivity in healthy humans. Journal of Clinical Endocrinology \& Metabolism 201398 2536-2543. (doi:10.1210/jc.2012-4162)

Received in final form 7 May 2016

Accepted 23 May 2016
This work is licensed under a Creative Commons Attribution-NonCommercial 4.0 International License. 